\title{
Genetic Variability, Correlation and Path Analysis in Stem Amaranth (Amaranthus tricolor L.) Genotypes
}

\author{
M. Hasan*, C. A. Akther and M. S. Raihan \\ Department of Genetics and Plant Breeding, Bangabandhu Sheikh Mujibur Rahman Agricultural \\ University, Gazipur 1706, Bangladesh \\ *Corresponding author and Email: saikathu@yahoo.com
}

Received: 15 October 2012

Accepted: 18 May 2013

\begin{abstract}
Seventeen genotypes of stem amaranth (Amaranthus tricolor L.) were evaluated to determine the genetic variability, degree of association between yield and its component characters. The direct and indirect effects of marketable yield were also evaluated. High heritability with high genetic advance as percent of mean was registered for number of leaf, leaf weight and marketable yield which in fact demonstrated the presence of additive gene effects. The correlation studies revealed strong positive association of yield with leaf weight, stem weight, stem diameter, dry weight with rind, and dry weight without rind. The relationship was non-significant and negative at $1^{\text {st }}$ flowering. The result of path analysis indicated that stem weight had maximum direct effect on marketable yield followed by leaf weight, leaf number and dry weight without rind.
\end{abstract}

\section{Keywords: Stem amaranth, heritability, correlation, path analysis}

\section{Introduction}

Amaranth (Amaranthus tricolor L.) is a widespread traditional vegetable in all countries of tropical world including Bangladesh. It is one of the main leafy vegetables in this country and consumed as a vegetable dish or as an ingredient of sauces. Amaranth is recognized as an easy-togrow and extremely productive and nutritious vegetable. As amaranth is the most important popular vegetable crop during summer and rainy season, it is very important to evaluate the available genotypes and to select the improved ones with high yield potential and good quality.

Yield of stem amaranth is a complex character like those of other crops which is determined by various components. Knowledge on genetic variability exists among different parameters is important for crop improvement. Heritability, which measures phenotypic variance and is attributable to genetic causes, is another important consideration for a successful breeding program. Correlation coefficient analysis is a handy technique, which elaborates the degree and extent of relationship among important plant characters and it provides basic criteria for selection which leads to directional model based on yield and its components in the field experiments. Path coefficient analysis, on the other hand, is an efficient statistical technique specially designed to quantify the interrelationship of different components and their direct and indirect effects on yield. Through this technique yield contributing characters and specific traits producing a given correlation can be categorized (Islam et al., 2010).

However, information regarding inheritance of yield and its closely related components is 
essential to efficiently exploit the available genetic diversity in stem amaranth for yield. The present study was therefore, undertaken to find out and establish suitable selection criteria for stem amaranth genotypes through study of genetic variability, heritablility, genetic advance and relationship between marketable yield and its components.

\section{Materials and Methods}

Seventeen genotypes of stem amaranth were grown in a randomized complete block design with three replications at the experimental field laboratory, Department of Genetics and Plant Breeding, Bangabandhu Sheikh Mujibur Rahman Agricultural University (BSMRAU), Gazipur in 2008. The experimental materials were collected from different agro-ecological regions of Bangladesh (Table 1). The seeds were sown in the seed bed of $1 \mathrm{~m} \times 1 \mathrm{~m}$ and the seed beds were $50 \mathrm{~cm}$ apart from each other. All agronomic and plant protection measures were done as per schedule. Data on yield contributing traits have been recorded from ten randomly selected plants from each genotype in each replication.
Data were recorded on first flowering, plant height, leaf number, leaf length, leaf weight, stem weight, stem diameter, dry weight with rind, dry weight without rind and marketable yield. The genotypic and phenotypic variances were calculated according to Singh and Choudhary (1985). Genotypic and phenotypic co-efficients of variations were computed using the formula suggested by Burton (1952) and AlJibouri et al. (1958). Heritability in broad sense was estimated according to Lush (1943). Genetic advance under selection was calculated by the formula suggested by Johnson et al. (1955). Genetic advance in percent of mean was calculated according to the method given by Comstock and Robinson (1952). Simple correlation co-efficients for all possible pair of characters at phenotypic and genotypic levels were done following Hayes et al. (1955). Direct and indirect effects were worked out using path analysis at genotypic level following Dewey and Lu (1959). The residual effect was calculated using the formula suggested by Singh and Choudhary (1985).

Table 1. List of variety and sources of stem amaranth

\begin{tabular}{ccc}
\hline Sl. No. & Variety name & Source \\
\hline G1 & Rangpur1 & Rangpur \\
G2 & Green tower & East-West Seed Company \\
G3 & Sureshawry1 & Faridpur \\
G4 & Vhutan & Jhenaidah \\
G5 & Red tower & East-West Seed Company \\
G6 & Baspata & Jessore \\
G7 & Panna & East-West Seed Company \\
G8 & Sarupa & Jessore \\
G9 & Rangpur2 & Rangpur \\
G10 & Suresh danta & Faridpur \\
G11 & Pryashi & Gazipur \\
G12 & Jessore \\
G13 & Aman (Red) & Jessore \\
G14 & Vhutan (Jamboo) & Gazipur \\
G15 & Rupali & Jessore \\
G16 & Sureshawry2 & BARI, Gazipur \\
G17 & BARI-1 & BARI, Gazipur \\
\hline
\end{tabular}




\section{Results and Discussion}

\subsection{Genetic variability, heritability and genetic advance}

The genotypes varied significantly for all the characters studied. The estimates of range, mean, genotypic variance $\left(\sigma^{2} \mathrm{~g}\right)$, phenotypic variance $\left(\sigma^{2} p\right)$, genotypic coefficient of variation (GCV), phenotypic coefficient of variation (PCV), broad sense heritability $\left(\mathrm{h}_{\mathrm{b}}^{2}\right)$, genetic advance (GA) and genetic advance in percent of mean (GA\%) for different characters are presented in Table 2. The ranges were moderate to high for most of the characters. Maximum range was observed in marketable yield (68.4 - $495.2 \mathrm{gm})$ followed by stem weight $(62.7-450.4)$ and number of leaves per plant (37.0 - 238.0). The differences between GCV and PCV were high for leaf length and stem diameter indicating the vulnerability of traits to environmental influences. High GCV and PCV were observed in leaf weight (77.54 and $80.14 \%$, respectively) and dry weight without rind (74.42 and $74.47 \%$ respectively). High heritability estimates associated with fairly high estimates of genetic advance (GA) were observed for number of leaf, leaf weight and marketable yield which in fact demonstrated the presence of additive gene effects. Such a high GA may be due to the action of additive genes (Abhay et al., 2002).

Table 2. Estimation of genotypic variance, phenotypic variance, environmental variance for yield and its component characters in stem amaranth

\begin{tabular}{|c|c|c|c|c|c|c|c|c|c|c|}
\hline 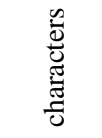 & Range & Mean & $\sigma^{2} \mathrm{~g}$ & $\sigma^{2} p$ & $\sigma^{2} \mathrm{e}$ & GCV & PCV & $\begin{array}{l}\mathrm{h}^{2} \mathrm{~b} \\
(\%)\end{array}$ & G.A & $\begin{array}{l}\text { G.A } \\
(\%)\end{array}$ \\
\hline $\mathrm{FF}$ & & & 332.1 & 332.15 & 0.00 & 49.49 & 49.49 & 100.0 & 37.54 & 101.96 \\
\hline $\mathrm{PH}$ & $77.5-143.9$ & 106.5 & 305.3 & 308.57 & 3.21 & 16.41 & 18.09 & 98.96 & 35.81 & 43.1 \\
\hline $\mathrm{LN}$ & $37.0-238.0$ & 107.5 & 2735.3 & 2742.2 & 6.93 & 48.63 & 51.11 & 99.75 & 107.6 & 128.22 \\
\hline LL & $13.12-26.80$ & 20.01 & 10.59 & 11.63 & 1.04 & 16.26 & 21.36 & 91.04 & 6.4 & 40.96 \\
\hline LW & $8.21-168.35$ & 50.24 & 1517.2 & 1538.9 & 21.74 & 77.54 & 80.14 & 98.59 & 79.67 & 203.24 \\
\hline SW & $62.7-450.4$ & 163.6 & 9943.63 & 9960.3 & 16.68 & 60.96 & 63.46 & 99.83 & 205.2 & 160.8 \\
\hline SD & $11.80-33.20$ & 19.40 & 39.4 & 40.57 & 1.17 & 32.35 & 37.92 & 97.12 & 12.74 & 84.18 \\
\hline $\begin{array}{l}\text { DW } \\
\text { (WR) }\end{array}$ & 7.07-38.42 & 16.68 & 71.82 & 72.09 & 0.27 & 50.81 & 50.91 & 99.62 & 17.43 & 133.88 \\
\hline $\begin{array}{l}\text { DW } \\
\text { (WOR) }\end{array}$ & $1.95-23.15$ & 7.785 & 33.56 & 33.61 & 0.05 & 74.42 & 74.47 & 99.85 & 11.92 & 196.31 \\
\hline MY & $68.4-495.2$ & 179.5 & 11793.4 & 11802.2 & 8.83 & 60.52 & 62.18 & 99.93 & 223.6 & 159.65 \\
\hline
\end{tabular}

$\mathrm{FF}=$ First flowering, $\mathrm{PH}=$ Plant height, $\mathrm{LN}=$ Leaf number, $\mathrm{LL}=$ Leaf length, $\mathrm{LW}=$ Leaf weight, $\mathrm{SW}=\mathrm{Stem}$ weight, $\mathrm{SD}=$ Stem diameter, DWWR = Dry weight with rind, DWWOR= Dry weight without rind, MY= Marketable yield. G.Ad. = Genetic advance, G.Ad. in \% mean $=$ Genetic advance in percentage of mean GCV= genotypic coefficient of variance, $\mathrm{PCV}=$ phenotypic coefficient of variance. 


\subsection{Correlation coefficients}

Genotypic and phenotypic correlation coefficients among yield and its components are presented in Table 3. In some cases, the genotypic correlation coefficients were higher than the phenotypic correlation coefficients. These observations indicate that the expressions of character associations had not been appreciably influenced by the environment and the apparent association may be largely due to genetic reason. The difference between genotypic and phenotypic correlation was in general low, indicating that the environmental effects did not have much influence on these characters. Dutta et al. (2002) also reported that the magnitudes of genotypic correlation were higher than their respective phenotypic correlations. Yield per plant showed significant and positive genotypic and phenotypic correlation with leaf weight, stem weight, stem diameter, dry weight with rind, dry weight without rind.

Table 3. Genotypic and phenotypic correlation among yield and its component characters in stem amaranth

\begin{tabular}{|c|c|c|c|c|c|c|c|c|c|c|}
\hline & & $\mathrm{PH}$ & $\mathrm{LN}$ & LL & LW & SW & SD & WRDW & $\begin{array}{c}\text { WORD } \\
\text { W }\end{array}$ & MY \\
\hline \multirow[t]{2}{*}{$\mathrm{FF}$} & $r_{g}$ & -0.099 & 0.344 & -0.142 & -0.005 & -0.116 & -0.041 & -0.147 & -0.460 & -0.128 \\
\hline & $r_{p}$ & -0.099 & 0.344 & -0.136 & -0.005 & -0.116 & -0.041 & -0.147 & -0.460 & -0.128 \\
\hline \multirow{2}{*}{$\mathrm{PH}$} & $\mathrm{r}_{\mathrm{g}}$ & & -0.006 & -0.265 & -0.218 & 0.214 & -0.295 & 0.153 & 0.196 & 0.187 \\
\hline & $\mathrm{r}_{\mathrm{p}}$ & & -0.005 & -0.246 & -0.213 & 0.213 & -0.290 & 0.155 & 0.195 & 0.186 \\
\hline \multirow[t]{2}{*}{$\mathrm{LN}$} & $r_{\mathrm{g}}$ & & & $0.549 *$ & $0.696 * *$ & 0.459 & 0.459 & $0.480^{*}$ & 0.195 & 0.472 \\
\hline & $r_{p}$ & & & $0.530 *$ & $0.691 * *$ & 0.458 & 0.452 & $0.478^{*}$ & 0.193 & 0.472 \\
\hline \multirow{2}{*}{ LL } & $\mathrm{r}_{\mathrm{g}}$ & & & & $0.834 * *$ & 0.460 & $0.646^{* *}$ & 0.235 & 0.387 & $0.489 *$ \\
\hline & $r_{p}$ & & & & $0.798 * *$ & 0.440 & $0.617^{* *}$ & 0.221 & 0.369 & 0.470 \\
\hline \multirow{2}{*}{$\begin{array}{l}\mathrm{L} \\
\mathrm{W}\end{array}$} & $r_{g}$ & & & & & $\begin{array}{c}0.755 \\
* *\end{array}$ & $0.809 * *$ & 0.474 & $0.567 *$ & $0.780 * *$ \\
\hline & $r_{p}$ & & & & & $\begin{array}{c}0.748 \\
* *\end{array}$ & $0.791 * *$ & 0.469 & $0.563^{*}$ & $0.774 * *$ \\
\hline \multirow{2}{*}{ SW } & $r_{g}$ & & & & & & $0.583 *$ & $0.614^{* *}$ & $0.760^{* *}$ & $0.999 * *$ \\
\hline & $r_{p}$ & & & & & & $0.574 *$ & $0.613^{* *}$ & $0.759 * *$ & $0.998 * *$ \\
\hline \multirow[t]{2}{*}{ SD } & $\mathrm{r}_{\mathrm{g}}$ & & & & & & & 0.277 & 0.397 & $0.602 * *$ \\
\hline & $r_{p}$ & & & & & & & 0.273 & 0.393 & $0.594 *$ \\
\hline \multirow{2}{*}{$\begin{array}{l}\text { W } \\
\text { RD } \\
\text { W }\end{array}$} & $\mathrm{r}_{\mathrm{g}}$ & & & & & & & & $0.741 * *$ & $0.611 * *$ \\
\hline & $\mathrm{r}_{\mathrm{p}}$ & & & & & & & & $0.739 * *$ & $0.610 * *$ \\
\hline \multirow{2}{*}{$\begin{array}{c}\text { W } \\
\text { OR } \\
\text { D } \\
\text { W }\end{array}$} & $r_{g}$ & & & & & & & & & $0.764 * *$ \\
\hline & $r_{p}$ & & & & & & & & & $0.764 * *$ \\
\hline
\end{tabular}

$\mathrm{FF}=1$ st flowering, $\mathrm{PH}=$ plant height, $\mathrm{LN}=$ leaf number, $\mathrm{LL}=$ leaf length, $\mathrm{LW}=$ leaf weight, $\mathrm{SW}=$ stem weight, $\mathrm{SD}=$ stem diameter, DWWR = Dry weight with rind, DWWOR= Dry weight without rind, MY= marketable yield, $\mathrm{rg}=$ Genotypic correlation $\mathrm{rp}=$ phenotypic correlation 
Plant height had positive correlation with stem weight, dry weight with rind, dry weight without rind and marketable yield. Positive significant correlations were also noticed for leaf length with leaf number, weight of leaf with leaf number and leaf length, stem diameter with leaf length, leaf weight and stem weight. Stem weight exhibited positive and significant correlation with dry weight both for rind and without rind. Length of leaf showed highly significant positive correlation with marketable yield both at phenotypic and genotypic levels.

\subsection{Path analysis}

The cause and effect relationships of yield per plant and yield related characters are presented in Figure 1. Residual effects of their independent variables, which have influenced yield to a small extent, are denoted as $\mathrm{R}$ in the diagram. Estimates of direct and indirect effects of path coefficient are presented in Table 4. Days to first flowering contributed minimum negative direct effect with marketable yield (-0.024). This character, however, showed highest negative indirect effect via marketable yield $(-0.128)$, stem weight (-0.11) and dry weight without rind $(-0.003)$. There was no effect with leaf weight (0.00). Plant height had the highest negative direct effect on marketable yield (-0.008). Leaf number showed positive direct effect with marketable yield (0.008). However, there was no effect with plant height (0.00). Leaf length showed the negative direct effect with marketable yield $(-0.022)$. This character also showed negative indirect effect with stem diameter (-0.010) and dry weight with rind (0.004), but result was ultimately the total positive significant correlation with marketable yield $(0.489 *)$. Leaf weight showed the maximum direct positive effect with marketable yield (0.090) and revealed no effect with days to first flowering (0.00), which resulted ultimately the total positive significant correlation with marketable yield.

Table 4. Path analysis showing direct (diagonal) and indirect (off-diagonal) effect of yield components on marketable yield of 17 stem amaranth genotypes

\begin{tabular}{ccccccccccc}
\hline & FF & PH & LN & LL & LW & SW & SD & WW & WOW & MY \\
\hline FF & $\mathbf{- 0 . 0 2 4}$ & 0.001 & 0.003 & 0.003 & 0.000 & -0.110 & 0.001 & 0.002 & -0.003 & -0.128 \\
PH & 0.002 & $\mathbf{- 0 . 0 0 8}$ & 0.000 & 0.006 & -0.020 & 0.203 & 0.005 & -0.003 & 0.001 & 0.187 \\
LN & -0.008 & 0.000 & $\mathbf{0 . 0 0 8}$ & -0.012 & 0.063 & 0.436 & -0.007 & -0.008 & 0.001 & 0.472 \\
LL & 0.003 & 0.002 & 0.004 & $\mathbf{- 0 . 0 2 2}$ & 0.075 & 0.437 & -0.010 & -0.004 & 0.003 & $0.489^{*}$ \\
LW & 0.000 & 0.002 & 0.005 & -0.018 & $\mathbf{0 . 0 9 0}$ & 0.717 & -0.013 & -0.008 & 0.004 & $0.780^{* *}$ \\
SW & 0.003 & -0.002 & 0.004 & -0.010 & 0.068 & $\mathbf{0 . 9 5 1}$ & -0.009 & -0.010 & 0.005 & $0.999 * *$ \\
SD & 0.001 & 0.002 & 0.004 & -0.014 & 0.073 & 0.554 & $\mathbf{- 0 . 0 1 6}$ & -0.005 & 0.003 & $0.602 * *$ \\
DWWR & 0.003 & -0.001 & 0.004 & -0.005 & 0.043 & 0.584 & -0.004 & $\mathbf{- 0 . 0 1 7}$ & 0.005 & $0.611^{* *}$ \\
DWWO & 0.011 & -0.002 & 0.002 & -0.008 & 0.051 & 0.723 & -0.006 & -0.012 & $\mathbf{0 . 0 0 7}$ & $0.764 * *$ \\
R & & & & & & & & & & \\
\hline
\end{tabular}

$\mathrm{FF}=1$ st flowering, $\mathrm{PH}=$ plant height, $\mathrm{LN}=$ leaf number, $\mathrm{LL}=$ leaf length, GCMY=genetic coefficient of marketable yield $\mathrm{LW}=$ leaf weight, $\mathrm{SW}=$ stem weight, $\mathrm{SD}=$ stem diameter, $\mathrm{WW}=$ with rind dry weight, WOW=without rind dry weight, Residual effect, $\mathrm{R}=0.011$ 


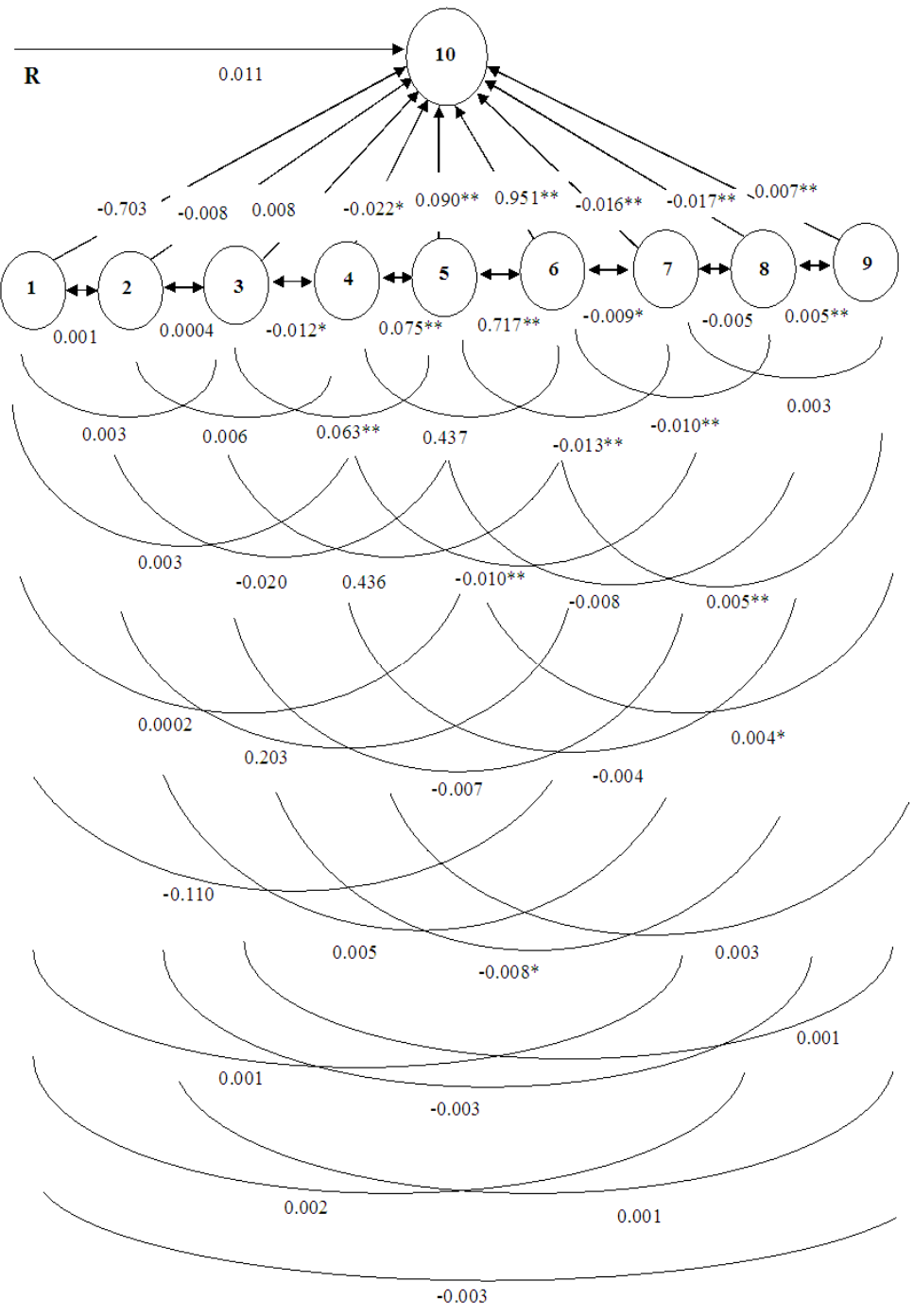

Fig.1. Path diagram of 9 yield contributing traits in stem amaranth

1 - 1st flowering, 2 - plant height, 3 - leaf number, 4 - leaf length, 5 - leaf weight, 6 - stem weight, 7 - stem diameter, 8 - dry weight with rind, 9 - dry weight without rind weight, 10 - marketable yield and $\mathrm{R}$ - residual effect

Stem weight showed highest positive direct effect with marketable yield (0.951). This trait also contributed positive effect via leaf weight per plant $(0.068)$ followed by dry weight without rind (0.005), leaf number (0.004) and days to first flowering (0.003). Negative indirect effects were revealed by dry weight with rind $(-0.010)$, leaf length $\quad(-0.010)$, stem diameter $(-0.009)$ and plant height (-0.002) making the total correlation between stem weight and marketable 
yield positive and highly significant (0.999*). Minimum negative direct effect with marketable yield (-0.016) was observed for stem diameter. Stem diameter showed maximum positive indirect effect (0.554) through stem weight followed by leaf weight per plant (0.073), leaf number per plant (0.004), dry weight without rind (0.003), plant height (0.002) and days to first flowering (0.001). This character also showed negative indirect effect with leaf length $(0.014)$ and dry weight with rind (-0.005). This negative direct effect was counter balanced by six positive indirect effect making the total correlation between stem diameter and marketable yield positive and highly significant $(0.602 * * *)$.

Dry weight with and without rind showed the negative and positive direct effect with marketable yield, respectively $(-0.017$ and $0.007)$. Nonetheless, these traits showed positive and negative indirect effect making the total correlation between dry weight and marketable yield positive and highly significant. The estimated residual effect was 0.011 indicating that about $99.99 \%$ of the variability in stem amaranth yield was contributed by the characters studied in this experiment.

\section{Conclusions}

The present study was undertaken to estimate the genetic parameters, association of different yield contributing characters and their direct and indirect effects on marketable yield of some stem amaranth genetypes. Additive gene effect was noticed for number of leaf, leaf weight and marketable yield as high heritability with high genetic advance was recorded. Marketable yield exhibited strong positive association with leaf weight, stem weight, stem diameter, dry weight with rind and dry weight without rind. Path analysis indicated that stem weight had maximum direct effect on marketable yield. It would therefore, be rewarding to lay stress on these characters in selection program for increasing marketable yield of the stem amaranth genotypes.

\section{References}

Abhay, D., Nagda A. K. and Dashora A. 2002. Genetic variability and character association in Spanish bunch groundnut. Researches on Crops, 3(2): 416-420.

Al-Jibouri, H. A., Kitter, P. A. and Robinson, H. F. 1958. Genotypic and environmental variations and co-variances in an upland cotton cross of interspecific origin. Agronomy Journal, 50: 533 - 536.

Burton, G. W. 1952. Quantitative inheritance in grasses. Proceeding on $6^{\text {th }}$ International Grass Conservation, 277 - 283 pp.

Comstock, R. E and Robinson, H. F. 1952. Estimation of average dominance of genes. In: Heterosis J. H Gowen (ed). Iowa State College Press, USA, 494 - 516 pp.

Dewey, D. R. and Lu, K. H. 1959. A correlation and Path coefficient analysis of components of erected wheat grass seed production. Argonomy Journal, 51: 515 518.

Dutta, M., Prasad R., Saini G. C. and Bandyopadhyay, B. B. 2002. Genetic Variability, Correlation and Path Analysis in Amaranth. Indian Journal of Plant Genetic Resources, 15(2): 186 - 188.

Hayes, H. K., Immer, F. R. and Smith, D. C. 1955. Methods of Plant Breeding. $\left(2^{\text {nd }}\right.$ edition). Mc. Grow Hill Book Co; Ins. New York. 551 p.

Islam, B. M. R., Ivy, N. A., Rasul, M. G. and Zakaria, M. 2010. Character association and path analysis of exotic tomato (Solanum lycopersicum L.) genotypes. Bangladesh Journal of Plant Breeding and Genetics, 23(1): $13-18$.

Johnson, H. W., Robinson, H. F. and Comstock, R. E. 1955. Estimation of genetic and environmental variability in soybeans. Agronomy Journal, 47: 314 - 318.

Lush, J. L. 1943. Animal Breading Plans. Iowa State College Press, Ames, Iowa. 437 p.

Singh, S. P. and Choudhary, B. D.1985. Biometrical Methods in Quantitative Genetic analysis. Kalyani Publishers, New Delhi. 57 p. 